\title{
THE PROGRESSIVE EXPORT TAX AND INDONESIA'S PALM OIL PRODUCT EXPORT COMPETITIVENESS
}

\section{Hubungan Pajak Ekspor Progresif dengan Daya Saing Ekspor Produk Kelapa Sawit Indonesia}

\author{
Immanuel ${ }^{1}$, Suharno ${ }^{2}$, Amzul Rifin $^{2}$ \\ ${ }^{1}$ Ministry of Trade, Jl. M.I. Ridwan Rais No.5, Jakarta, 10110, Indonesia \\ 2Department of Agribusiness, Bogor Agricultural University \\ Jl. Kamper, Kampus IPB Darmaga, Bogor, West Java, 16680, Indonesia \\ E-mail: immanuel.alfonsus@yahoo.co.id
}

Naskah diterima: 24/05/2018; Naskah direvisi: 23/04/2019; Disetujui diterbitkan: 29/11/2019

Dipublikasikan online: 31/12/2019

\begin{abstract}
Abstrak
Hubungan antara daya saing produk kelapa sawit dan intervensi kebijakan pemerintah di Indonesia masih sering menjadi perdebatan diantara pemangku kepentingan. Terkait dengan hal tersebut, penelitian ini menganalisis hubungan antara pajak ekspor progresif dengan perubahan pangsa ekspor CPO Crude Palm Oil (CPO) dan Refined Palm Oil (RPO) serta mengkaji daya saing kedua komoditi. Metode yang digunakan adalah Revealed Compared Advantage (RCA) dan Export Product Dynamic (EPD) untuk mengukur perubahan pangsa ekspor serta tingkat daya saing produk CPO dan RPO ke negara tujuan utama ekspor. Untuk melihat dampak kebijakan tersebut, kajian ini membandingkan sebelum dan sesudah diberlakukannya kebijakan pajak ekspor progresif pada akhir tahun 2007 dan menggunakan data bulanan ekspor produk CPO dan RPO periode 1997-2018. Hasil analisis menunjukkan bahwa setelah diberlakukannya pajak ekspor progresif, pada komoditi CPO telah terjadi penurunan pangsa ekspor sebesar $21 \%$ dan pergeseran tingkat daya saing produk dari posisi Rising Star ke Lost Opportunity. Sebaliknya pada komoditi RPO terjadi peningkatan pangsa ekspor dan daya saing dari Falling Star ke Rising Star. Peningkatan pangsa ekspor dan daya saing RPO merupakan salah satu pencapaian dari tujuan kebijakan pajak ekspor. Analisis ini memberikan catatan penting bagi pemerintah dalam membuka alternatif pasar baru dengan tetap mempertahankan pangsa ekspor di negara tujuan ekspor utama.
\end{abstract}

Kata Kunci: CPO, Pajak Ekspor, Daya saing, RCA, EPD

\begin{abstract}
The relationship between Indonesia's palm oil product competitiveness and the government's policy intervention is still disputable among stakeholders. This research analyzes the association between the progressive export tax and the changes in export shares of Crude Palm Oil (CPO) and Refined Palm Oil (RPO) as well as the competitiveness of both commodities. Revealed comparative advantage (RCA) and export product dynamic (EPD) are used to measure the change in the export shares of CPO and RPO as well as of their export competitiveness to the main destination countries. To examine the impact of this policy, this research compares before and after the enactment of a progressive export tax policy at the end of 2007 and uses monthly export data for CPO and RPO products for the period 19972018. The result finds that after the enactment of the progressive export tax of CPO, the export share of CPO declined by $21 \%$ and the level of competitiveness of CPO products moved from Rising Star to Lost Opportunity compared with the condition during 1997-2007. In contrast, the export share of RPO products increased and its competitiveness level moved to a better position from Falling Star to Rising Star. Although shifting the export value of both CPO and $R P O$, as one of the objectives of the implementation of the export tax, was achieved, this study
\end{abstract}


is highlighting essential commentary in which policymaker still needs to search for new export markets while maintaining export shares in the main export destinations.

Keywords: CPO, Export Tax, Competitiveness, RCA, EPD

JEL Classification: Q17, F13, O24

\section{INTRODUCTION}

The estate crop sector as a one of sources of Indonesia's foreign exchange has big contribution for developing economy in Indonesia. The major commodities of Indonesia's crop sector are Crude Palm Oil (CPO), Rubber, Cocoa, and Coffee. From those, Indonesia is the biggest producer and exporter CPO in the world, Malaysia as the second. During 2001-2017, on average per year, world CPO's export value to all countries reached 7.2 Billion USD, $55.9 \%$ or around 4 Billion USD comes from Indonesia (UN COMTRADE, 2019).

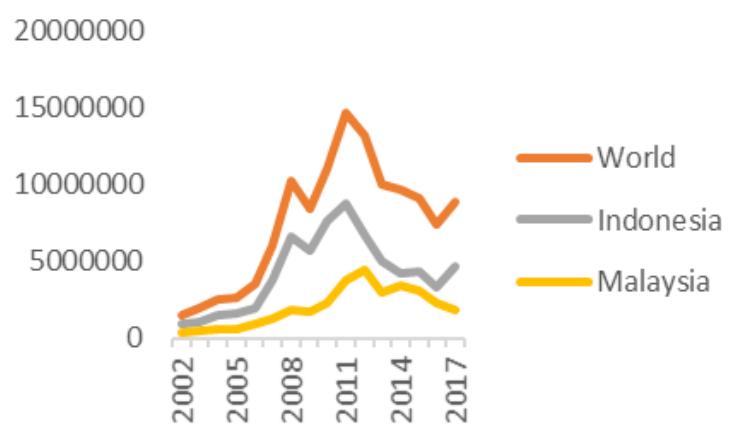

Figure 1. Crude Palm Oil (HS 151110) World Export Value (1000 USD)

Source: UN COMTRADE (2019)

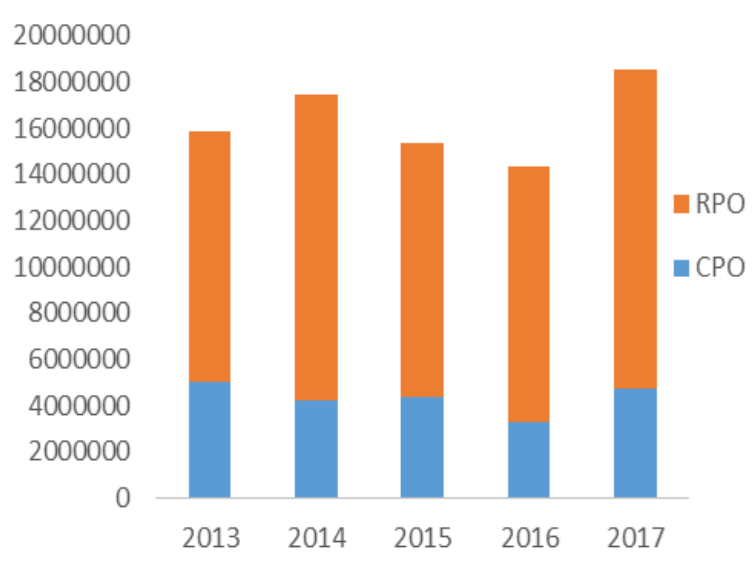

Figure 2. Palm Oil and Its Fraction (HS 1511) World Export Value (1000 USD)

Source: UN COMTRADE (2019)

World palm oil production is dominated by Indonesia and Malaysia. Both countries produce about $85 \%$ to $90 \%$ of the total world's palm oil. The dependency of the world on palm oil products from Indonesia is indicated by the worldwide high consumption of vegetable oil in which palm oil has the biggest share. In 2018 the total world vegetable oil need reached 191 million tons per year, to which Indonesia supplied 18\% (Statista, 2019).

Palm oil is exported in two primary forms: CPO and Refined Palm Oil (RPO). In 2017, the Indonesian CPO as a staple commodity is mostly exported to India $(65,3 \%)$, the Netherlands $(8,8 \%)$ 
and Malaysia (8,5\%). The imposition of the progressive export tax by the government in 2007 has changed the composition of the export volume in the last nine years. The export tax policy aims to guarantee the availability of palm oil in domestic market, to control the domestic palm oil price, in particular to keep the cooking oil price stably, to develop the downstream industry of palm oil which has value added, and to encourage export of value-added products. As it was intended, the composition of the Indonesian palm oil exports shifted to the downstream product during 2013-2017, as illustrated in the figure 2.

According to WTO agreement, this regulation has included in tariff policy that is not forbidden. However, it can affect the competitiveness of export of CPO and RPO products due to the increasing of the new price of both. Because of the direct connection between this policy and the compositions of shares in the export of CPO and RPO, hence, it is important to answer two research questions such as: 1) How is the progressive export tax related to the change in the share export of CPO and RPO?; 2) How is the relation of progressive export tax on the competitiveness of the export of Indonesia's CPO and RPO?

One of the most general method to measure competitiveness based on market approach is market share or the change in market share (Rifin 2010a). Based on the previous explanation, this paper aims to measure the change in the export shares and in the competitiveness of export of both products to main country of destination in relation to the imposition of the progressive export tax. In addition, this paper suggests RCA and EPD analysis to predict how policy implemented by the Indonesian government affect the transformation in the export shares as well as the competitiveness of export of both products on the international CPO market.

\section{Empirical Studies of Export Tax on} Agricultural Commodities

In order to maintain the economic situation inside globalization era, almost all countries have been cooperating in many sectors. The limitation of resource or input production is causing them to flow products and services from other countries including Indonesia. Some previous studies described international trade such as Hsu and Tuan (2001); Pujiati (2014); Nugroho (2014); and 
Kania (2014). All these researches used similar concept from The HeckscjerOhlin $(\mathrm{H}-\mathrm{O})$ theory, which emphasizes the interaction between the different proportions of the country's production factors, as well as the differences in the usage of these factors on producing a wide range of items. Feenstra and Taylor (2008) revealed The $\mathrm{H}-\mathrm{O}$ model predicts that a country tends to export the good, which uses its abundant factor intensively. The H-O Model is explaining that a country will export commodity that possesses not only the low price of production factors but also in much quantities. Conversely, a country will import commodity that the production of it will absorb the high price and rare of production factors (Salvatore, 1997).

The flowing of product and service among countries has couple of barriers that are called tariff and nontariff barriers. One of the types of the tariff barriers is export tax. Many researchers investigated the consequences of export tax on Palm Oil products. Hasan et al (2001); Obado et al (2009); Rifin (2010b); Rachman (2012); Rifin (2012); Purba (2012); Abdulla et al (2014); Rifin (2014); Syadullah (2014); Immanuel et al (2016); Immanuel et al (2018) found that the imposition of export tax was followed by the decline in the level of competitiveness of Palm Oil products.

Since this policy led to change the share export of commodity, there are several studies that have analyzed the market share of agricultural commodity as an indicator of competitiveness of the commodity in global market. Using the method of market share, Rifin (2010a); Chen \& Buwajian (2012); Nurcahyani et al (2018) identified the competitiveness of agricultural commodities as an impact on the implementation of special multilateral agreement with the main trading partners as well on the market transition from one producer country to others.

Applying the method of Revealed Comparative Advantage (RCA), Hassan (2013); Elryah (2014); Kanaya \& Firdaus (2014); Sari (2015); Prasetyo et al (2017) analyzed comparative advantage of the export of agricultural products in international market. All of authors have similar type of data and also tool of analysis. They used time series data from some institutions with the minimum lag of time analysis for ten years. Examining the comparative advantages can be continued with the measurement of the competitive 
advantage by using another method that is called Export Product Dynamic (EPD). Hasibuan et al (2012); Ningsih (2013); Sunardi (2015), Setyawati (2015); Mulatsih and Putri (2017); Wiranthi and Mubarok (2017) analyzed the position of market of one country for specific market destination. Researchers used EPD for mapping the level of competitiveness of Indonesia's agricultural commodities and textile.

\section{Impact of Trade Policy}

The Indonesian government applied the export tax policy of Palm Oil commodity and its fraction since September 1994. This policy has two objectives, namely (i) stabilizing the inventory of the raw material that will use for oil cooking industry and (ii) developing the downstream Industry of Palm Oil. Figure 3 illustrates the condition of exporting country in term of the effect of export taxes at the rate of $t$.

The domestic price of export falls to $\mathrm{Pt}$, reducing the sum of consumer and producer surplus by the area of $\mathrm{PfDCP}_{\mathrm{f}}$.

However, the tax yields revenue equal to after-tax volume multiplied by the tax rate or the area of $\mathrm{P}^{*} \mathrm{t} A C \mathrm{Pt}_{\mathrm{t}}$. The loss of tax is equal to the area of BCD, while the terms of trade gain is equal to the area of $\mathrm{P}^{*}{ }_{t} \mathrm{ABP}_{\mathrm{f}}$ (Helpman and Krugman, 1989).

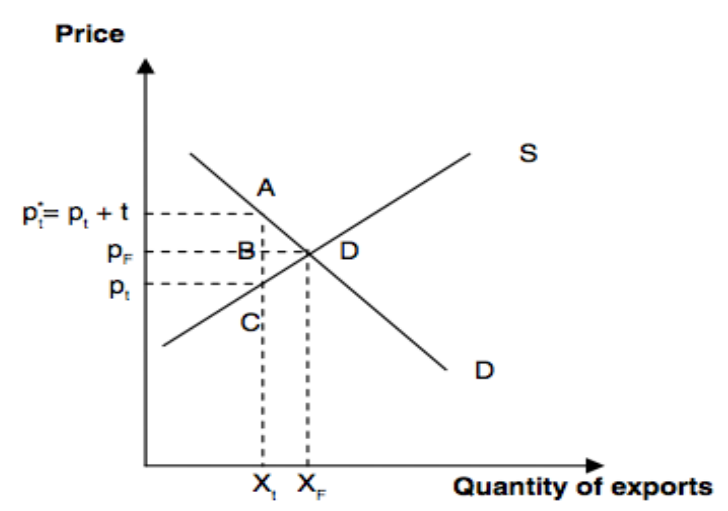

Figure 3. The Application of Export Tax

Source: Helpman \& Krugman (1989)

\section{Theory of Competitiveness}

Each country has a different level of competitiveness. Following the economic perspective, there are some indicators for measuring the competitiveness such as The Domestic Resource Cost, The Constant Market Share, The Revealed Comparative Advantage, and Trade Specialization Ratio (Porter, 1990).

The competitiveness of a commodity especially regarding the comparative advantage is not only related to natural or artificial factors. Salvatore (1997) revealed that all sources of comparative advantage of a country could be obtained by the learning factor which is usually referred to as dynamic advantage. Meanwhile, 
the comparative advantage using labor and capital is usually called static advantage. Indonesia as a developing country has a static advantage through the excess supply of labor, however the developed countries as providers of technology have a dynamic advantage. One method for measuring the comparative advantage of a country is the revealed compared advantage method (RCA).

The comparative advantage of a country is not automatically followed by a competitive advantage. The result of the combination of the vertical agribusiness beginning with input markets, on-farm and local markets and ending with export-import is called competitive advantage. In order to raise the competitive advantage, it is necessary to develop a robust cooperation between the on-farm sector and the off-farm sector of agribusiness. Furthermore, the competitive advantage of a commodity and its dynamic movement can be measured by using the export product dynamic method (EPD).

\section{METHODOLOGIES}

On 2007 the Government of Indonesia changed the mechanism of export tariffs for palm oil and its derivatives from constant export tax to progressive export tax. The new calculation of export tariff has been determined based on reference prices at applicable in international prices. As a consequence, if international prices rise, export tax of CPO will also increase (Hafizah 2011). In addition, this policy was implemented because of the increase in the international price of CPO without followed by the increasing of export tariff, it was successfully encouraging producer of $\mathrm{CPO}$ to export its product rather than supplying $\mathrm{CPO}$ to domestic market (Rifin 2014).

As a complement to previous research, it is interesting to find out regarding to the changing of the export shares as well as the competitiveness of export of both products particularly before and after the implementation of the progressive export tax of CPO of Indonesia. Thereby, this study uses a market approach that it can be predicted by the changing of export share. In other words, if CPO or RPO product from Indonesia has a larger export share, these product is more competitive in a certain period and specific country destination. RCA and EPD method are used to analyze the competitiveness advantage i.e competitiveness of CPO 
and RPO exports to the main destination countries.

\section{Revealed Comparative Advantage (RCA)}

The competitiveness of the CPO or RPO of one country can be measured by the RCA index. The export performance of these products is a variable measured by calculating the share of CPO or RPO exports in the total exports of all commodities to the main partner countries, compared with the share of these commodities in the world exports to the same destination countries.

The equation of the RCA index is the following:

$$
R C A=\frac{X_{i j} / X_{t j}}{W_{i j} / W t j}
$$

where:

$\mathrm{X}_{\mathrm{ij}}=$ Export value of $\mathrm{CPO}$ or RPO commodity from Indonesia to destination country

$X t j=$ Total export value for all commodities from Indonesia to destination country

Wij $=$ The world export value of CPO or RPO commodity to destination country

$\mathrm{Wtj}=$ Total value of world exports to destination country
The competitiveness is explained by the interpretations of two results of the RCA index. Firstly, RCA $>1$ shows that the share of CPO or RPO export in the total export of Indonesia is higher than the share of CPO or RPO export in the world export. In other words, Indonesia has comparative advantage in CPO or RPO export, which can be categorized as a big player in the field of those products.

On the other hand, $\mathrm{RCA}<1$ means that the share of CPO or RPO export in the total export of Indonesia is lower than the share of export of CPO and RPO export in total world export. It implies that Indonesia does not have comparative advantage in CPO or RPO export and is, therefore, not a dominant player in the CPO or RPO world market.

\section{Export Product Dynamic}

The market position of the export of one product from one country to a specific destination country can be determined by using EPD. This method allows to assess the movement of a commodity in the international market based on the level of growth of this commodity during a certain period. It can also be applied to the movement of CPO and RPO commodity. 
Mathematically, the X-axis can be simulated as follows:

$X=\frac{\sum_{t=1}^{t}\left(\frac{X i j}{W i j}\right) t \times 100 \%-\sum_{t=1}^{t}\left(\frac{X i j}{W i j}\right) t-1 \times 100 \%}{T}$

By contrast, the $\mathrm{Y}$-axis is formulated as follows:

$$
Y=\frac{\sum_{t=1}^{t}\left(\frac{\mathrm{Xt}}{W t}\right) \mathrm{t} \times 100 \%-\sum_{t=1}^{t}\left(\frac{\mathrm{Xt}}{W t}\right) t-1 \times 100 \%}{T}
$$

Where, $t$ is the year and $T$ is number of year analysis.

An EPD matrix consist of market attractiveness and business-strength information. The former is calculated based on growth in demand for a product in a certain market destination, while the rest is measured based on growth in the country's market share of a particular market destination (Bappenas, 2009). The market position of one product can be categorized using a matrix that is divided into four levels.

Figure 4 consists of four areas depicting export levels based on the market share. All the levels make the indicator of competitiveness visible in a quantitative way. In a market, rising star is the best position of a product which rapidly develops a higher export share value (being part of the group of the fastgrowing products). Lost opportunity describes the circumstance of a commodity decreasing in export share value. Falling star shows the enhancing of the market share value of a product, although it does not grow in a dynamic market. Retreat can be explained as a commodity not needed by the market.

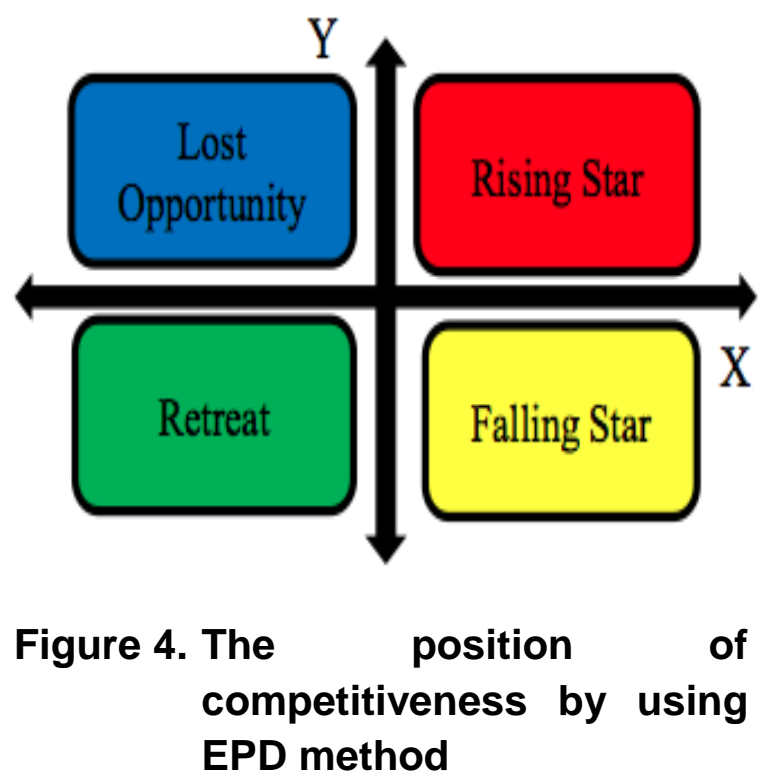

Source: Estherhuizen (2006)

The position in the quadrants represents the growth of Indonesia's market share for all commodities to the destination country (placed in X-axis) and the growth of market share for Indonesia's CPO or RPO to the destination country (placed in $\mathrm{Y}$-axis). 
Table 1. EPD Position

Matrix Competitiveness

\begin{tabular}{lcc}
\hline $\begin{array}{l}\text { Share of Country's } \\
\text { in World trade }(\mathrm{x})\end{array}$ & \multicolumn{2}{c}{$\begin{array}{c}\text { Share of Product } \\
\text { in World Trade }(\mathrm{y})\end{array}$} \\
\cline { 2 - 3 } & $\begin{array}{c}\text { Rising/ } \\
\text { Dynamic }(+)\end{array}$ & $\begin{array}{c}\text { Falling/ } \\
\text { Stagnant }(-)\end{array}$ \\
\hline $\begin{array}{l}\text { Rising/ } \\
\text { Competitive (+) }\end{array}$ & Rising Star & Falling Star \\
\hline $\begin{array}{l}\text { Falling/non- } \\
\text { competitive }(-)\end{array}$ & Lost & Retreat \\
\hline
\end{tabular}

Source: Ningsih (2013)

\section{Data Description}

This study compares the shift of the export share value of Indonesia's CPO and RPO using data from eleven years before and after the implementation of the progressive export tax of $\mathrm{CPO}$ in 2008. The analysis uses yearly export data from 2007 to 2018 and estimation of RCA as well as EPD as an analysis method. In other words, this study compares the data from 1997-2007 with those from 2008-2018. Thereby, the changing of the structure of the export value including $\mathrm{CPO}$ and RPO is calculated. The top three destination countries of Indonesia's CPO export are India, the Netherlands and Malaysia. In contrast, China, Pakistan and India are the main importer countries of Indonesia's RPO commodity.

This research uses secondary data available from various sources. Indonesia's palm oil export data to the main destination countries during 19972018 has been generated by the Trade Statistic for International Business Development and further combined with the United Nations Commodity Trade Statistic Database (UN COMTRADE).

The palm oil and its fraction product has the Harmonized System (HS) code 1511 and is divided into Crude Palm Oil (HS code: 151110) and Refined Palm Oil but no chemically modified (HS code: 151190).

\section{RESULTS AND DISCUSSION}

Indonesia's Structure Export of Palm Oil Products

For evaluating how the progressive export tax influenced the changing of the export share of CPO and RPO, it is necessary to examine the structure of the export shares of both commodities.

In 1997-2007, the export value of Palm Oil and Its Fraction product (HS 1511) from Indonesia to the world reached 2.7 billion US $\$$ and increased to 15.4 billion US\$ in 2008-2018, which is a growth of $466 \%$. The reason for the increasing of the export value of Palm Oil and Its Fraction product is the especially high demand by the two biggest importers of its commodity, China and India. These countries use 
CPO for the production of Biodiesel (Immanuel et al, 2018).

Table 2. Structure of Indonesia's Palm Oil and Its Fraction export (HS 1511)

\begin{tabular}{ccccc}
\hline & $1997-2007$ & \multicolumn{3}{c}{$2008-2018$} \\
\cline { 2 - 5 } Palm & $\begin{array}{c}\text { Average } \\
\text { Oil }\end{array}$ & $\begin{array}{c}\text { Average } \\
\text { Value } \\
\text { (Billion } \\
\text { USD/Year) }\end{array}$ & $\begin{array}{c}\text { Value } \\
\text { (Billion } \\
\text { USD/Year) }\end{array}$ & $(\%)$ \\
\hline CPO & 1,6 & 57 & 5,5 & 36 \\
RPO & 1,5 & 43 & 9,9 & 64 \\
Total & 2,7 & 100 & 15,4 & 100 \\
\hline
\end{tabular}

Source: Author's calculation based on UN COMTRADE (2019)

The export of palm oil and its fraction is dominated by CPO product achieving a contribution of $57 \%$ at the time before the implementation of the progressive export tax while the remaining $43 \%$ are contributed by $\mathrm{RPO}$ product. Yet, in 2008-2018, the contribution of RPO product to the export value climbed to $64 \%$, whereas CPO product declined to $36 \%$ in its contribution. This indicates that the implementation of Indonesia's progressive export tax for CPO altered the export contribution by CPO and RPO product (Purba, 2012; Rifin, 2014; Immanuel et al, 2016; Immanuel et al, 2018). In addition, the result of the application of export tax on palm oil product is in line with the second elements of implementing of export tax policy which is reducing the volume export of CPO (Helpman and Krugman, 1989).

Based on table 3, China as the biggest importer country of Indonesia's RPO commodity was the destination of the highest growth of export after the introduction of this policy. The export of RPO product to China sharply increased by $511 \%$. Beside imposing the export tax policy, there are other important factors affecting this growth such as the increasing consumption of food and beverages made from palm oil products in China as well as the decreasing consumption of other types of vegetable oils, e.g. soybean oil.

Table 3. Structure of Indonesia's RPO Export (HS 151190)

\begin{tabular}{ccccc}
\hline & \multicolumn{2}{c}{$\mathbf{1 9 9 7 - 2 0 0 7}$} & $\mathbf{2 0 0 8 - 2 0 1 8}$ \\
\cline { 2 - 5 } Country & $\begin{array}{c}\text { Average } \\
\text { Value } \\
\text { (Billion } \\
\text { US } \$ \text { Year) }\end{array}$ & $\begin{array}{c}\text { Average } \\
\text { Value }\end{array}$ & $\begin{array}{c}\text { (Billion } \\
\text { US\$/Year) }\end{array}$ & $(\%)$ \\
\hline China & 0,30 & 19,6 & 1,86 & 18,9 \\
Pakistan & 0,12 & 7,6 & 0,81 & 8.2 \\
India & 0,28 & 17,8 & 1,27 & 12,8 \\
Others & 0,86 & 55 & 5,94 & 60,1 \\
Total & 1,56 & 100 & 9,88 & 100 \\
\hline
\end{tabular}

Source: Author's calculation based on UN COMTRADE (2019)

In line with the result of research by Rifin (2010a), there are several arguments for the immense growth of the Asian market including China for both products, CPO and RPO. The significant amelioration of the economic 
condition in China encouraged the demand for palm oil products particularly in regard to the food and oleo-chemical industry.

Table 4. Structure of Indonesia's CPO Export (HS 151110)

\begin{tabular}{|c|c|c|c|c|}
\hline \multirow[b]{2}{*}{ Country } & \multicolumn{2}{|c|}{$1997-2007$} & \multicolumn{2}{|l|}{$2008-2018$} \\
\hline & $\begin{array}{l}\text { Average } \\
\text { Value } \\
\text { (Billion } \\
\text { US\$/Year) }\end{array}$ & $(\%)$ & $\begin{array}{l}\text { Average } \\
\text { Value } \\
\text { (Billion } \\
\text { US\$/Year) }\end{array}$ & $(\%)$ \\
\hline India & 0,46 & 39,9 & 2,81 & 51,2 \\
\hline Netherland & 0,18 & 15,3 & 0,65 & 11,8 \\
\hline Malaysia & 0,10 & 8,4 & 0,46 & 8,4 \\
\hline Others & 0,42 & 36,4 & 1,58 & 28,6 \\
\hline Total & 1,16 & 100 & 5,50 & 100 \\
\hline
\end{tabular}

Source: Author's calculation based on UN COMTRADE (2019)

A positive effect on Indonesia's Palm Oil export to China can also be seen in the abolishing of China's Tariff Rate Quota (TRQ) for some commodities including Palm Oil in 2006 and the import tariff of palm oil product with a specified quantity being charged a low tariff (Hsu \& Tuan 2001). The Free Trade Agreement (FTA) also had a significant impact on Indonesia's palm oil export value to China. According to Pujiati (2014), after the China ASEAN Free Trade Agreement (CAFTA) the procurement of palm oil from trade partner countries increased. In other words, China imported more palm oil from Indonesia being the biggest exporter of this commodity. Besides this, the growth of Indonesia's RPO export after the implementation of the progressive export tax might be influenced by the development of the refinery industry in the main destination countries such as India and Pakistan. Referring to Kania (2014), black campaigns for Indonesia's Palm Oil products in countries of the European Union led to a switching of the market from Europe to Asia. Hence, in reference to table 4 , the export share to the Netherlands decreased from 15,3\% to $11,8 \%$ while the export share to India increased from $39,9 \%$ to $51,2 \%$.

The Comparative Advantage for Indonesia's CPO and RPO Commodities

The comparative advantage of palm oil commodities can be measured by the RCA method. Table 5 shows the RCA values for the top three largest importing countries of Indonesia's CPO and RPO products. Generally, the comparative advantage of Indonesia's CPO to the main destination countries has a very strong value especially in the Netherlands with an average RCA value reaching 77,01 within period 1997-2007. 
Table 5. Indonesia's RCA value for CPO (HS 151110) to selected countries from 1997-2007 compare with 2008-2018

\begin{tabular}{lcc}
\hline \multirow{2}{*}{ Country } & \multicolumn{2}{c}{ Average RCA of CPO } \\
\cline { 2 - 3 } & $1997-2007$ & $2008-2018$ \\
\cline { 2 - 3 } India & 27,18 & 27,29 \\
Netherland & 77,01 & 49,08 \\
Malaysia & 29,81 & 16,21 \\
\hline
\end{tabular}

Source: Author's calculation based on UN COMTRADE (2019)

In accordance with Nugroho (2014), the export growth of CPO to the Netherlands and India was induced by the increased demand of the cooking oil industry and also by the higher demand for the derivative products of the CPO industry, such as lotion and soap. Looking at Indonesia RCA value to the Malaysia, several arguments can be brought forward to support the result presented in the table. Firstly, Malaysia is an exporter of CPO and since 2002 this country also has CPO plantations of around 250,000 hectares in Indonesia to provide the necessary raw material for the RPO Industry in Malaysia. Secondly, this country also imports CPO from Indonesia to support the need for raw material of CPO of the RPO industry although Malaysia possesses palm oil plantations (Rifin, 2010b).

An effect of the enactment of the progressive export tax policy consisted in the reduction of the movement of Indonesia's CPO export value. Comparing the RCA values in figure 5 , we can obtain the diminishing points of the comparative advantage of CPO due to the implementation of the progressive export tax policy. In other words, the implementation of this policy led the changing of structure of Indonesia's CPO export into derivatives products (Syadullah, 2014).

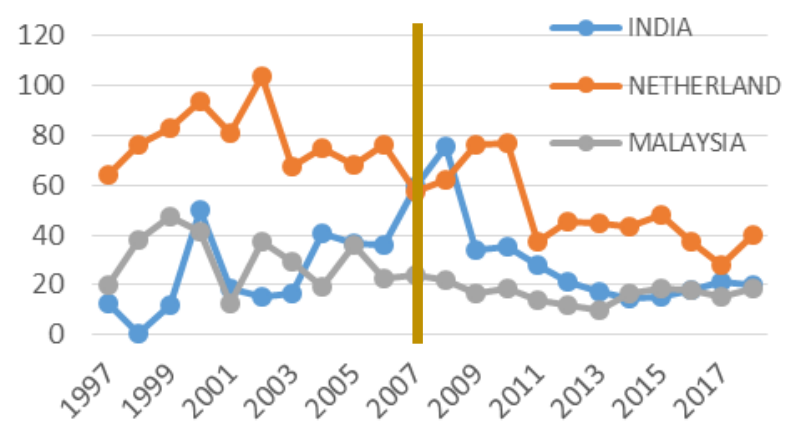

Figure 5. The Graphic of RCA Value of Indonesia's CPO (19972018)

Source: Author's calculation

The trend of the RCA value of the top three destination countries goes down after 2007. After 2007 as the year which was chosen to divide the observation time of this study, it was predictable that the export of CPO to the potential markets would decrease after the introduction of the progressive export tax. According to Obado et al (2009), it can be affirmed that the export tax policy reduced the competitiveness 
of the Indonesian palm oil industry which was detrimental to the producers of CPO.

The comparative advantage of Indonesia's RPO can be explained by comparing the average RCA value in table 6 . This can clearly be seen by the RCA value of each importing country being higher than one in the period between 1997 and 2018 .

China has a positive growth shown by the fact that the share of RPO commodity in the total export from Indonesia to China is higher than the average share of the world export of RPO to China in all world exports to this country. The stability of growth of the export of RPO to China during this time has a robust impact on the level of the comparative advantage of RPO.

Table 6.Indonesia's RCA Value for RPO (HS 151190) to Selected Countries from 1997-2007 Compare with 2008-2018

\begin{tabular}{ccc}
\hline \multirow{2}{*}{ Country } & \multicolumn{2}{c}{ Average RCA of RPO } \\
\cline { 2 - 3 } China & $1997-2007$ & $2008-2018$ \\
\cline { 2 - 3 } India & 21,31 & 39,98 \\
Pakistan & 43,98 & 35,25 \\
\hline
\end{tabular}

Source: Author's calculation based on UN COMTRADE (2019)

The trend of the export to China is described by figure 6 , capturing the increase of the RCA value. Conversely, the other countries showed a declining RCA value. The highest RCA value for China was achieved in 2015.

Indonesia obtained benefit from the decision by the government of China in 2015 to substitute the consumption of vegetable oil produced from soybeans with the consumption of palm oil. Because soybean oil nowadays comes from genetically modified organisms (GMOs), the China consumption of vegetable oil was diverted away from soybean oil to palm oil. This caused an increase of demand of China for palm oil from Indonesia.

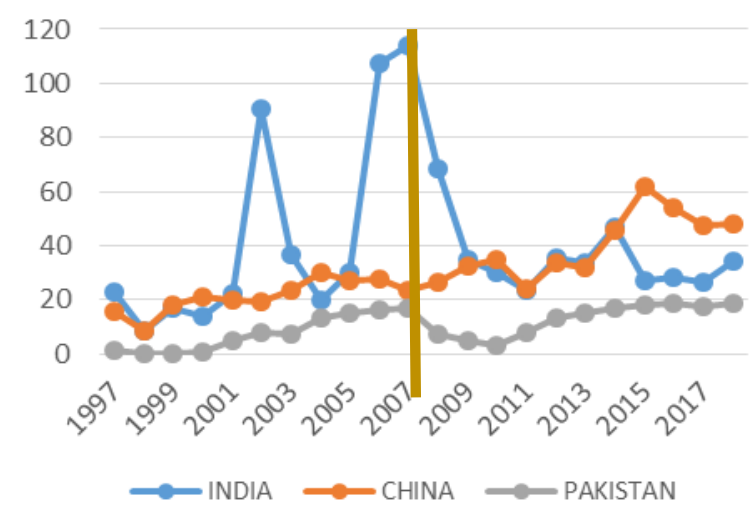

Figure 6. The Graphic of RCA Value of Indonesia's RPO (19972018)

Source: Author's calculation

India as the second biggest importer of Indonesia's RPO possesses a bad record of the RCA value after 2007 due to the new decision of the government of India to apply a duty of 
$7,5 \%$ on the import of CPO and Soybean oil.

India's import duty trimmed the supply of palm oil from Indonesia to India. Meanwhile, the RCA value to Pakistan slowly decreased beginning from 2008 because of the agreement between the governments of Pakistan and Malaysia to sign the Preferential Trade Agreement (PTA) in November 2007 to cut the price of palm oil products imported from Malaysia by a $10 \%$ discount of the duty. This agreement encouraged Pakistan to move from Indonesia's palm oil to Malaysia's product. Thereby, Indonesia's palm oil exports decreased beginning from 2007 to 2010 and it is reflected by a declining of the RCA value. This problem was solved by the government of Indonesia by following the same strategy to make an agreement with Pakistan in 2009. Indonesia and Pakistan agreed to sign a PTA in March 2009 to reduce $10 \%$ of its import duty on Indonesia's CPO product (Rifin, 2010a).

\section{Competitive Advantage for Indonesia's CPO and RPO Commodities}

By using the sample data of the main destination countries of $\mathrm{CPO}$ or
RPO commodity, is possible to analyze the extent of the competitive advantage of these products to those countries. The result of the EPD method for the CPO product is shown in table 7 .

The estimation result in table 7 describes that the overall position of CPO's market share has to be classified as Lost Opportunity within 2008-2018, except for Netherland which is stable on Retreat. This means that under these circumstances the export share value of CPO commodity decreased (Estherhuizen, 2006). This position was unexpected and Indonesia lost the chance to expand the cover area of this product in the international market. The result might indicate that the influence of the progressive exports tax of CPO in Indonesia changed the level of competitive advantage of CPO product. In the period from 1997 to 2007 , some countries still have a higher level of competitiveness i.e. India and Malaysia having a Rising Star position. Meanwhile, Netherland's position was not altered and stayed in the position of Retreat. 
Table 7. Indonesia's EPD Position for CPO to Selected Countries, 1997-2018

\begin{tabular}{|c|c|c|c|c|c|c|}
\hline \multirow[t]{2}{*}{ Country } & \multicolumn{2}{|c|}{$\begin{array}{l}\text { Average of the growth of } \\
\text { Indonesia's market share } \\
\text { for all commodities (\%) }\end{array}$} & \multicolumn{2}{|c|}{$\begin{array}{l}\text { Average of the growth of } \\
\text { market share for } \\
\text { Indonesia's CPO } \\
\text { commodity (\%) }\end{array}$} & \multicolumn{2}{|c|}{ EPD } \\
\hline & 1997-2007 & $2008-2018$ & 1997-2007 & $2008-2018$ & 1997-2007 & $2008-2018$ \\
\hline India & 11,13 & $-7,34$ & 0,08 & 0,04 & Rising Star & $\begin{array}{c}\text { Lost } \\
\text { Opportunity }\end{array}$ \\
\hline Netherland & $-8,33$ & $-1,21$ & $-0,03$ & $-0,004$ & Retreat & Retreat \\
\hline Malaysia & 3,61 & $-0,44$ & 0,19 & 0.08 & Rising Star & $\begin{array}{l}\text { Lost } \\
\text { Opportunity }\end{array}$ \\
\hline
\end{tabular}

Source: Author's calculation based on UN COMTRADE (2019)

Indonesia is the main supplier on CPO and RPO's market in India. However, due to India's policy change in increasing duty for CPO and RPO up to three times since August 2017, Indonesia' $s$ export on CPO and its derivative has been significantly decreased. Firstly, start from $11^{\text {st }}$ of August to $17^{\text {th }}$ of November 2017 India was imposing the import duty of CPO from $7,5 \%$ to $15 \%$ or it was increasing

1997-2007

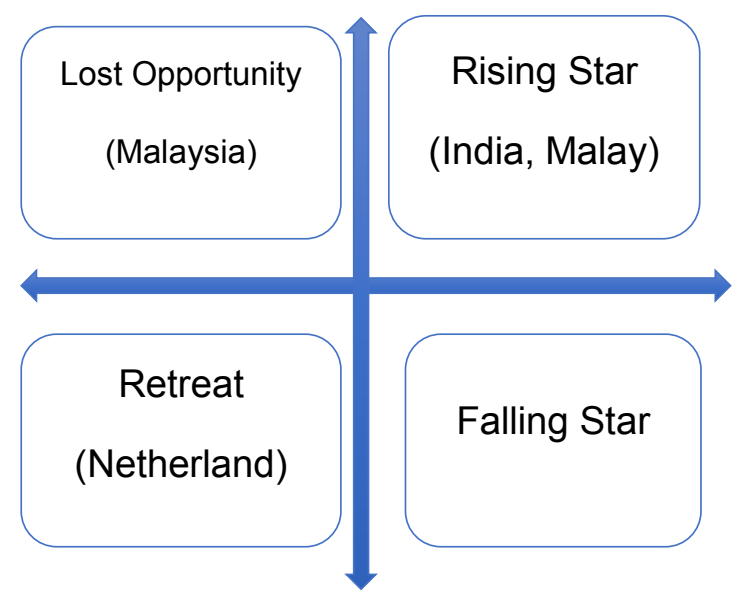

$100 \%$ of import duty for CPO commodity. Secondly, within period of $17^{\text {th }}$ of November 2017 to $28^{\text {th }}$ of February 2018, the import duty of CPO from Indonesia to India has increased from $15 \%$ to $30 \%$. Lastly, by $1^{\text {st }}$ of March 2018, the import duty was jumped by government of India from $30 \%$ to $44 \%$. For this additional reasons, India's position has changed from a Rising Star to a Lost Opportunity.

2008-2018

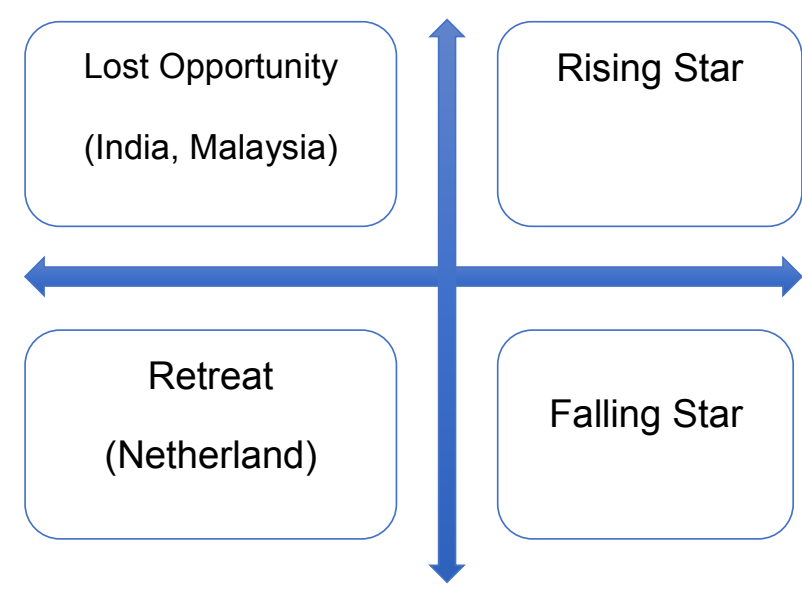

Figure 7. The position of Competitiveness of Indonesia's CPO

Source: Author's calculation 
The Netherlands is the biggest importer of CPO among the European Union (EU) countries because of the existence of the port of Rotterdam as the center of CPO exports in Europe. As the price of CPO is cheaper than another vegetable oils, the supply of palm oil products significantly affects European economics (PASPI, 2014). The Increasing of consumption of CPO in the EU has influenced the increasing of EU's dependence on CPO commodity. To overcome it, EU countries developed other vegetable oils such as Rapeseed, soybean oil, canola oil, and sunflower oil and they conducted a black campaign against CPO (Kania, 2014).

The issue of negative campaign on the Indonesian palm oil products in the world market particularly the EU due to many forest fires in Indonesia during the second half of 2015 (Immanuel et al, 2016). Recently, the EU Commission, acknowledge in a platform of Renewable Energy Directive (RED) II or delegated act, had decided that palm oil cultivation causes significant deforestation, and thus Biodiesel produced from palm oil cannot be counted towards meeting ET green fuel targets (IIASA 2015). Furthermore, the
EU Parliament and national governments agreed to phase out the use of the highest emitting biofuels or high Indirect Land Use Change (ILUC) risk biofuel by 2030 .

Indonesia's CPO should prove that its meet three pillars of sustainability to cope an issue of black campaign. In other words, CPO products which exported should be completed by palm oil certification that is recognized by imported countries. Certification of CPO product, part of Technical Barrier to Trade, would impede the export trade flow of Indonesian CPO (Sari, 2015).

Malaysia, one of the world's largest palm oil exporter, has imported CPO from Indonesia. Palm oil production in Malaysia has increased over the years in line with the development of the industry of refining of CPO. On 1997, the production of CPO in Malaysia reached 8,5 million tons, it sharply increased to 20,5 million tons on 2018. The growth in CPO production in Malaysia had affected import CPO from Indonesia which can be showed by the shifting Malaysia's position from a Rising Star to a Lost Opportunity.

Based on table 8, Indonesia's RPO commodity has a better position 
compared with CPO in terms of the level of competitive advantage. The position of RPO product in China upgraded from Falling Star position to Rising Star.
The average value of the growth of Indonesia's market share for all commodities to China increased from $1.63 \%$ to $3.43 \%$.

\section{Table 8. Indonesia's EPD Value for RPO to Selected Countries 1997-2018}

\begin{tabular}{ccccccc}
\hline Country & $\begin{array}{c}\text { Average of the } \\
\text { growth of } \\
\text { Indonesia's market } \\
\text { share for all } \\
\text { commodities (\%) }\end{array}$ & $\begin{array}{c}\text { Average of the } \\
\text { growth of market } \\
\text { share for } \\
\text { Indonesia's RPO } \\
\text { commodity (\%) }\end{array}$ & EPD & \\
\cline { 2 - 7 } & $1997-2007$ & $2008-$ & $1997-$ & $2008-$ & $1997-2007$ & $2008-2018$ \\
\cline { 2 - 7 } China & 1,63 & 3,43 & $-0,03$ & 0,02 & $\begin{array}{c}\text { Falling } \\
\text { Star }\end{array}$ & Rising Star \\
India & 21,50 & $-15,04$ & 0,08 & 0,04 & $\begin{array}{c}\text { Rising Star } \\
\text { Lost }\end{array}$ & $\begin{array}{c}\text { Opportunity } \\
\text { Rising Star }\end{array}$ \\
Pakistan & 4,26 & 2,51 & 0,17 & 0,11 & Rising Star & Re18 \\
\hline Source: Author's calculation based on UN COMTRADE (2019) &
\end{tabular}

In addition, the average of the growth of market share of Indonesia's RPO commodity to China also increased from $-0.03 \%$ to $0.02 \%$. As mentioned before, since China ASEAN Free Trade Agreement (CAFTA), the $1997-2007$
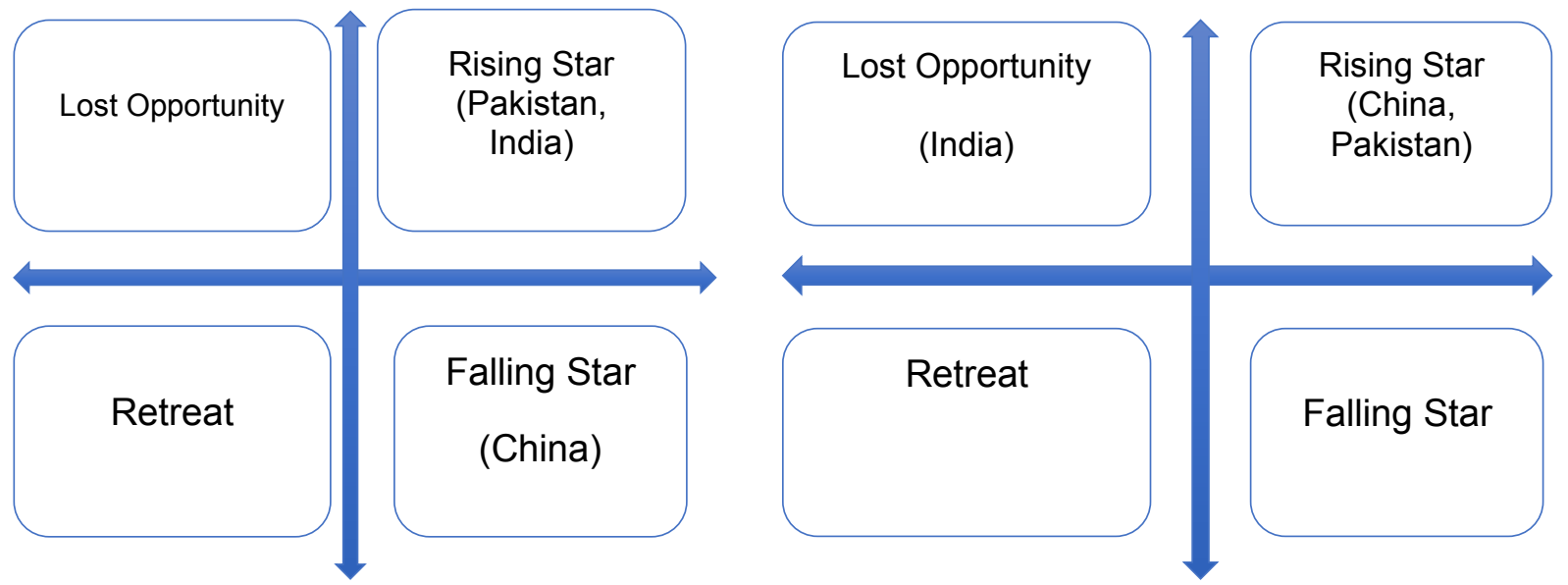

Figure 8. The position of competitiveness of Indonesia's RPO

Source: Author's calculation 
Palm Oil export from Indonesia to China has shown significant growth as China decreased soybean import from the US following the trade war between the two countries. Palm oil import from Indonesian climbed $63 \%$ to 541.81 thousand tons on October 2018 from 332.52 thousand tons on September 2018. This circumstances drive a China's position from a Falling Star to a Rising Star.

India, one of Indonesia's largest markets for RPO shipments, had decided to raise import duties on RPO from $15 \%$ on August 2017 to $25 \%$ on November 2017 , then it up to $40 \%$ on December 2017. Lastly, the import duty increased to $54 \%$ on March 2018.

Eventually, both tariffs, progressive export tax and import duty had changed the position of Indonesian RPO in India market from a Rising Star to a Lost Opportunity.

The competitiveness of export of Indonesian RPO to Pakistan stable on a Rising Star position. However, the level of competitiveness in both sides decline. It falls amount to $1,75 \%$ in the average value of the growth of Indonesia's market share for all commodities to Pakistan and it also drops amount to $0,06 \%$ in the average of the growth of market share of Indonesia's RPO commodity to Pakistan. As a hub country in the middle east and south east Asia, Pakistan expected to become the new backbone of Indonesia Palm Oil exports. In other words, the government of Indonesia needs to protect the market share of palm oil export to Pakistan by accelerate the ratification process of PTA that it will benefits one of Indonesia's RPO product.

\section{CONCLUSION AND POLICY RECOMMENDATIONS}

The progressive export tax export successfully detracted the volume export of CPO and increased the volume export of RPO. Since The government of Indonesia applied the progressive export tax of Palm Oil products, it was followed by a decrease in the export share of CPO amount to $21 \%$ which has moved to an increase in the export share of RPO and also the change in the level of competitiveness of CPO product from Rising Star to Lost Opportunity in particular for RPO's market to India and Malaysia. Meanwhile, Netherland's position was not altered and stayed in the position of Retreat. In contrast, RPO's market to China had a better position from Falling Star to Rising Star. For Pakistan's 
market, although there were declining of the level of competitiveness, Pakistan's position was stable in the position of Rising Star. RPO's competitiveness decreased in India's market from a Rising Star to a Lost Opportunity.

Besides the implementation of Indonesia's progressive export tax of Palm Oil and its derivative products, several conditions influenced the decreased of the supply of Indonesia's CPO to the international market and increased the export of RPO product derived from CPO product such as the trade agreement with the destination countries especially with Pakistan, import duties of CPO and RPO products in India, trade war between China and US, negative campaign against palm oil by EU countries and also the development of production of Malaysian Palm Oil. In addition, the flow of exports was not only affected by the implementation of this policy, but also by several other factors such as, the international price and the changing of the preference between the types of vegetable oil.

Under the revised export duty structure, the competitiveness of both commodities also changed in terms of comparative and competitive advantage. In this article, it became evident that Indonesia missed the level of comparative and competitive advantage of CPO product which is shown in the movement of the market share of the top three destination countries. However, there was also a positive impact in regards to the China market particularly for RPO product of which the average of the growth of market share still increases.

Government intervention in enhancing Palm Oil competitiveness, namely Indonesia Sustainable Palm Oil (ISPO) revamping program, a ratification process on PTA with Pakistan, and demand creation market of CPO such as Biodiesel and Green diesel program in local market are continuously to be applied.

Moreover, new market penetration into non-traditional markets could also be an option to expand the export share of Indonesia's CPO product in the international market. In addition, it might be better to set up one special board particular for palm oil sector hence Indonesian government much easier to control the whole internal system starts from upstream to downstream sector of palm oil. Furthermore, these board can be 
focused to acquire more non-traditional markets by setting special export tariff's structure as well as accelerate domestic market creation.

\section{ACKNOWLEDMENT}

The authors thank the Ministry of

Trade Republic of Indonesia and German Academic Exchange Service (DAAD) Scholarship for the support and sponsorship on dual degree program between Bogor Agricultural University and the University of Goettingen.

\section{REFERENCES}

Abdulla, I., Arshad, M, F., Bala, B, K., Noh, M, K., Tasrif, M. (2014). Impact of CPO Export Duties On Malaysian Palm Oil Industry. American Journal of Applied Sciences 11 (8): 1301-1309.

Bappenas. (2009). Trade and Investment in Indonesia: A Note on Competititveness and Future Challenge. Jakarta: Bappenas.

Chen, J., Buwajian, A. (2012). Analysis of China's Agricultural Exports to Five Asian Countries. Management Science and Engineering. Volume 6, No. 2: 96-102. 2012.

Elryah, Y. (2014). Back to the Agriculture The Development of The Comparative Advantage Of Sudan's Commodities. Xiamen University Xiamen, P. R. China. January 2015.

Estherhuizen, D. (2006). Measuring and Analyzing Competitiveness in The Agribusiness Sector: Methodological and Analytical Framework. University of Pretoria.

Feenstra, R. C., \& Taylor, A. M. (2008). International economics. New York: Worth Publishers.

Hafizah, D. (2011.) Study on Indonesian government policy on CPO trade using market integration approach. Journal of AGRISEP, pp. 10(2). September 2011.

Hasan, Mohamad F, Reed, Michael R, Marchant, Mary A. (2001). Effects of an Export Tax on Competitiveness: The Case of the Indonesian Palm Oil Industry. Journal of Economic Development. Vol. 26 No 2. December 2001.

Hassan, U, M, R. (2013). An Analysis of Competitiveness of Pakistan's Agricultural Export Commodities. Journal of Business and Management. Vol. 11, Issue 5: 29-34. July- August 2013.

Hasibuan, A., Nurmalina, R., Wahyudi, A. (2012). Analysis of Performance And Competitiveness of Indonesian Cocoa And Its Intermediate Products In The International Market. RISTRI Buletin Volume 3, No 1. 2012

Helpman, E., Paul R.K. (1989). Trade Policy and Market Structure. Cambridge: MIT Press.

Hsu, H.H. \& F. tuan. (2001). China's Accession to WTO Would Boost of Edible Oils. Paper Presented at the WCC-101 Conference, Sonoma, California, USA., April 8-10, 2001.

Immanuel., Khaliqi, M., Amiruddin, A. (2016). The effect of estate-crop fund on Indonesia's crude palm oil export competitiveness. Proceeding International Conference Strengthening Indonesian Agribusiness: Rural Development and Global Market Linkages. Department of Agribusiness, Bogor Agricultural University in collaboration with NICHE NUFFIC Programme-The Netherlands. April 2016.

Immanuel., Rifin, A., Suharno. (2018). Price Transmission and The Effect of Indonesia's Export Tax on Crude Palm Oil Prices. Master Thesis. Postgraduate School, Bogor Agricultural University, Bogor; Indonesia. 
International Institute for Applied Systems Analysis. (2015). The Land Use Change of Biofuels Consumed in The EU, Quantification of Area and Greenhouse Gas Impacts. October $2015 . \quad$ Retrieved from https://ec.europa.eu/energy/sites/ene r/files/documents/Final\%20Report G LOBIOM publication.pdf

Kanaya I, A., Firdaus, M. (2014). Daya saing dan permintaan ekspor produk biofarmaka Indonesia di negara tujuan utama periode 2003-2012. Jurnal Manajemen dan Agribisnis. Volume 11 No.3. November 2014

Kania, A. (2014). Analysis of Competitiveness and Determinants of Indonesian CPO Export to India and Netherlands. Bachelor Thesis. Agribusiness Department, Bogor Agricultural University, Bogor; Indonesia.

Mulatsih, S., Putri, R.N. (2017). Analysis of Indonesian Men's Apparel Exports to Seven Countries in European Union. Proceedings of the $2^{\text {nd }}$ International Conference on Indonesia Economy and Development (ICIED 2017). Advances in Social Sciences, Education and Humanities Research (ASSEHR), Volume 126. August 2017.

Ningsih, A. (2013). Analysis of Competitiveness and Factors that Affect The Demand of Indonesian Essential Oils in Export Country. Bachelor thesis. Economy Science Department, Bogor Agricultural University, Bogor; Indonesia.

Nurcahyani, M., Masyhuri, Hartono S. (2018). The Export Supply of Indonesian Crude Palm Oil (CPO) to India. Journal of Agro Economy of Gajah Mada University Volume 29 No.1. June 2018

Nugroho, S. (2014). Analysis of Affecting Factors in Indonesia's Crude Palm Oil and Palm Kernel Oil Export. Bachelor thesis. Resource and Environment
Economy Department, Bogor Agricultural University, Bogor; Indonesia.

Obado, J., Syaukat, Y., Siregar, H. (2009). The Impacts of Export Tax Policy On The Indonesian Crude Palm Oil Industry. Journal International Society for Southeast Asian Agricultural Sciences. Volume. 15 No. 2: 107-119. November 2009.

Palm Oil Agribusiness Strategic Policy Institute - PASPI. (2014). The Sustainability of Indonesian Palm Oil Industry. Bogor: PASPI.

Prasetyo, A., Marwanti, S., Darsono. (2017). Comparative Advantage and Export Performance of Indonesian Crude Palm Oil in International Markets. Journal of Agro Economy of Sebelas Maret University. Volume 35 No. 2. October 2017.

Porter, M. E. (1990). The Competitive Advantage of Nations. Harvard Business Review. Massachusetts (US): Harvard University.

Pujiati, R. (2014). The Impact of Free Trade Agreements on Commodity Trade Flows (Case Study: International Palm Oil Trade). Master Thesis. Postgraduate School, Bogor Agricultural University, Bogor; Indonesia.

Purba J, H, V. (2012). The Impact of Export Tax-Crude Palm Oil on Cooking Oil Industry in Indonesia. PhD Thesis. Postgraduate School, Bogor Agricultural University, Bogor; Indonesia.

Rachman, A. (2012). Market Integration and Price Transmission on the CPO and cooking oil markets in Indonesia. Master Thesis. Postgraduate School, Bogor Agricultural University, Bogor; Indonesia.

Rifin, A. (2010a). Export Competitiveness of Indonesia's Palm Oil Product. Trends in Agriculture Economics, 3(1), 1-18.

Rifin, A. (2010b). The Effect of Export Tax on Indonesia's Crude Palm Oil (CPO) 
Export Competitiveness. ASEAN Economic Bulletin 27, 1-18.

Rifin, A. (2012). The Impact of Export Tax Policy on Cocoa Farmers and Supply Chain In Indonesia. The International Trade Journal Volume 29. No. 1. January 2015.

Rifin, A. (2014). The Effect of Crude Palm Oil Export Tax on Export and Prices. ASEAN Journal of Economics, Management, and Accounting 2 (1\&2). November 2014.

Salvatore, D. (1997). Ekonomi internasional. Jakarta (ID): Erlangga

Sari, A.R. (2015). Analysis of Non-Tariff Measures on Export of Indonesian Crude Palm Oil (CPO) to the Main Export Destinations. Master Thesis. Postgraduate School, Bogor Agricultural University, Bogor; Indonesia.

Setyawati, D. (2015). The Prospect of Indonesian Export Product to Peru and Factors Affecting Its Trade Flow to South America. Master Thesis. Postgraduate School, Bogor Agricultural University, Bogor; Indonesia.

Statista. (2019). Statistical Data. Accessed
March 2019 at

https://www.statista.com/statistics/26

3937/vegetable-oils-global-

consumption/

Sunardi, D. (2015). Analysis of Competitiveness and Determinants Export of Priority Commodities from Indonesia to Organization of Islamic Cooperation (OIC). Master Thesis. Postgraduate School, Bogor Agricultural University, Bogor; Indonesia.

Syadullah, M. (2014). Impact Tax Policy on CPO Exports. Center of Policy of Macro Economy Ministry of Finance. Volume 18 No. 3. December 2018

United Nations Statistical Division. (2019). Tade Data (UN Comtrade) [Data file]. Retrieved from https://comtrade.un.org/data/

Wiranthi, P.E., Mubarok, F. (2017). Competitiveness and The Factors Affecting Export of The Indonesia Canned Pineapple In The World and The Destination Countries. $2^{\text {nd }}$ International Conference on Sustainable Agriculture and Food Security: A Comprehensive Approach. Volume 2017. November 2017 